\title{
Technè
}

La science au service de l'histoire de l'art et de la préservation des biens culturels

48 | 2019

Les couleurs de l'Antique

\section{Archaeometric analyses of the stuccoes and polychromy on temple C at Selinunte (Sicily)}

Analyse archéométrique des stucs et de la polychromie du temple C de Sélinonte en Sicile

Lorenzo Lazzarini, Katia D'Ignoti, Giovanni Alfano, Stefano Cancelliere and Carmelo Bennardo

\section{(2) OpenEdition}

Journals

Electronic version

URL: https://journals.openedition.org/techne/1711

DOI: 10.4000/techne. 1711

ISSN: 2534-5168

Publisher

C2RMF

\section{Printed version}

Date of publication: 31 December 2019

Number of pages: 6-13

ISBN: 978-2-11-152831-4

ISSN: 1254-7867

Electronic reference

Lorenzo Lazzarini, Katia D'Ignoti, Giovanni Alfano, Stefano Cancelliere and Carmelo Bennardo,

"Archaeometric analyses of the stuccoes and polychromy on temple $\mathrm{C}$ at Selinunte (Sicily)", Technè [Online], 48 | 2019, Online since 01 July 2021, connection on 03 April 2022. URL: http:// journals.openedition.org/techne/1711 ; DOI: https://doi.org/10.4000/techne.1711

La revue Technè. La science au service de l'histoire de l'art et de la préservation des biens culturels est mise à disposition selon les termes de la Licence Creative Commons Attribution - Pas d'Utilisation Commerciale - Pas de Modification 4.0 International. 


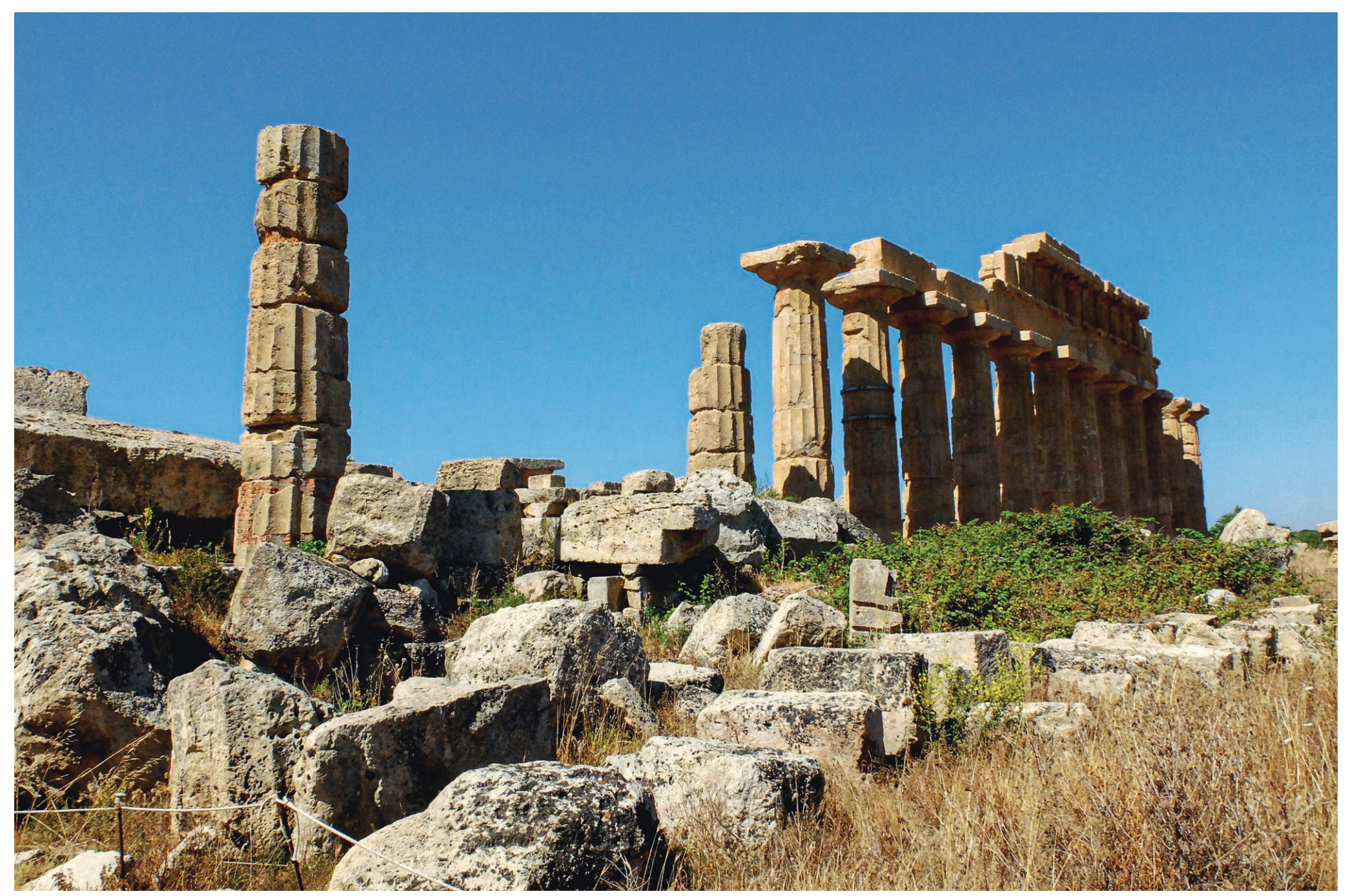

Fig. 1. Selinus, temple C, the northern peristasis in June 2017, after the last restoration. @ L. Lazzarini. 
Lorenzo Lazzarini

Katia D'Ignoti

Giovanni Alfano

Stefano Cancelliere

Carmelo Bennardo

\section{Archaeometric analyses of the stuccoes and polychromy on temple $\mathrm{C}$ at Selinunte (Sicily)}

Analyse archéométrique des stucs et de la polychromie du temple C de Sélinonte en Sicile

\begin{abstract}
Abtract. The most recent restoration of the re-erected part of temple C of ancient Selinus (modern Selinunte, Sicily) made it possible to carry out direct observations and a sampling campaign on the very few extant ancient stuccoes and polychromy traces on the columns and capitals of the northern peristasis. The samples were submitted to laboratory analyses including XRD on powder, $O M$, as well as SEM-EDS, on polished and thin sections, providing a stratigraphic reconstruction of the various stuccoes applied over the biocalcarenite of the temple. The composition of the stuccoes, together with that of the remaining polychromy, has been determined archaeometrically, thus allowing new hypotheses about the decorative materials and techniques used during the main lifetime (6th-5th centuries B.C.) of the temple.
\end{abstract}

Keywords. Selinus, temple C, stuccoes, polychromy, archaeometric analyses, stratigraphic units.
Résumé. La toute récente restauration de la partie reconstruite du temple C de l'antique Selinus (actuelle Sélinonte) a permis d'effectuer des observations directes et des prélèvements sur les rares traces de stucs et de polychromie conservées sur les colonnes et les chapiteaux du péristyle extérieur septentrional. Les échantillons ont fait l'objet d'analyses en laboratoire, comprenant la DRX (diffraction des rayons $X$ ) sur poudre, la MO (microscopie optique) et la MEB-SDE (microscopie électronique à balayage-spectroscopie à dispersion d'énergie) sur des lames minces polies, pour aboutir à une reconstitution stratigraphique des différents stucs appliqués sur la pierre en biocalcarénite du temple. La composition des stucs et celle de la polychromie résiduelle, déterminées par l'analyse archéométrique, soulèvent de nouvelles hypothèses quant aux matériaux et techniques employés pour la décoration durant la principale phase d'activité du temple (VI ${ }^{e}-V^{e}$ siècles av. J.-C.).

Mots-clés. Selinus, temple C, stucs, polychromie, analyse archéométrique, unités stratigraphiques.

\section{Introduction}

Temple C (fig. 1), generally dated around the middle of the 6th century B.C. and probably dedicated to Apollo ${ }^{1}$, is world famous for its beautiful archaic metopai discovered by William Harris and Samuel Angell in $1826^{2}$, now in the Salinas Museum of Palermo. It is the only temple partly re-erected in modern times on the acropolis of ancient Selinus (present-day Selinunte $)^{3}$, the westernmost Greek colony in Sicily. Temple C was considered the most suitable for reconstruction and as a landmark on the Selinuntine acropolis. The anastylosis of its northern peristasis was decided at the beginning of the 20th century and carried out by the engineer Francesco Valenti in the years spanning from 1924 to $1927^{4}$; it made a massive use of reinforced concrete with steel bars that later rusted and at times badly damaged the stone of the capitals and lintels ${ }^{5}$.
This resulted in the need for a long restoration effort in recent years (2011-2015). It took place in two phases. The first one was completed in 2012 and was a minor intervention with an emergency and experimental scope, but it included a complete survey, mainly conducted on the re-erected peristasis. Taking advantage of the scaffolding that allowed a close view of the surfaces, it was possible to collect information about the materials and building technique of the archaic Selinuntine temples ${ }^{6}$, as well as discover and study the traces of the original (and later, however ancient) stuccoes applied on the yellow biocalcarenite used for building the temple ${ }^{7}$. We refer to the "thin coating of fine plaster" that Harris and Angell saw "still remaining perfect on many parts of the architecture $^{8}$ " during the Selinuntine stage of their tour. Such stuccoes covered the surface of the biocalcarenite of the temples, as well as most of the other public monuments of the

Lorenzo Lazzarini, Prof. of Applied Petrography, LAMA (Laboratorio di Analisi dei Materiali Antichi), Università IUAV di Venezia, Italy (lorenzo@iuav.it). Katia D'Ignoti, Art Historian, L'ISOLA laboratori di restauro, Barcellona Pozzo di Gotto (ME), Italy (dignotika @ gmail.com). Giovanni Alfano, Architect, L'ISOLA laboratori di restauro, Barcellona Pozzo di Gotto (ME), Italy (arch.giovanni.alfano @ gmail.com). Stefano Cancelliere, Geologist, LAMA (Laboratorio di Analisi dei Materiali Antichi), Università IUAV di Venezia, Italy (cancellierestefano0@gmail.com). Carmelo Bennardo, Architect, Parco Archeologico della Valle dei Templi, Agrigento, Italy (carmelobennardo@gmail.com). 
Greek town. The use of a white stucco on the surface of soft limestone/calcarenites was very common in all Siceliot temples for more than one reason: it improved the aspect of the stones and made them look like marble ${ }^{9}$; it provided a flat surface suitable for polychromy ${ }^{10}$ and, finally, protected these highly porous stones ${ }^{11}$ from the very aggressive marine environment typical of all the major Greek coastal towns in Sicily ${ }^{12}$.

All these reasons are taken into account by Jakob Ignaz Hittorff in his publication L'Architecture polychrôme chez les Grecs, in which he rejects the ideal of whiteness characterizing the Neoclassical aesthetics of the 18th century ${ }^{13}$ : "Il appuie sur l'importante et juste remarque qu'indépendamment du bel aspect de la surface unie des stucs, en lieu et place de la vue désagréable d'une matière poreuse, cette application conservait essentiellement les pierres ; et il fait ressortir avec non moins de vérité combien le poli donné aux marbres et aux granits les plus durs, et la couche de cire cautérisée, la kav̄sıs, dont on couvrait ces précieux matériaux, aidaient à leur belle conservation et à leur durée $\mathrm{e}^{14}$."

Hittorff's reconstruction of the painted decoration of the small prostyle temple B at Selinus (of Early Hellenistic age, situated south of temple C), which he called "Temple of Empedocles", ignited the 19th century dispute about the polychromy of Greek architecture. According to Marconi, this intense controversy "infiamma per anni il mondo accademico francese, finendo con l'estendersi ad altri paesi europei ${ }^{15}$ ". Hittorff based his reconstruction on a detailed observation of the polychrome traces still partially preserved on the temple ${ }^{16}$. The 20th century saw the adoption of a more scientific approach to the study of ancient polychromy on statuary and architectural elements with important contributions ${ }^{17}$. These have continued, greatly multiplying in the present century ${ }^{18}$, also with the organization of permanent international round tables, the proceedings of which have often been published.

A first general archaeometric investigation of the materials and technique of the stuccoes, on several Selinuntine monuments, was conducted in 2009 by one of the authors of the present paper ${ }^{19}$. It allowed gathering useful information on these precious, scarce remains of ancient surface finishing treatment on public buildings, whose survival was already in great danger of loss due to the lack of ongoing restoration and maintenance. From 2006 onwards, the excavations and studies made on temple B by the New York University, under the direction of Clemente Marconi, have contributed to the overall knowledge of the ancient Selinuntine temple polychromy, and led to reconsider that such knowledge "differs significantly from those found in earlier literature, including that by Hittorff himself ${ }^{20 "}$.

\section{Experimental}

Our research on the surfaces of temple $\mathrm{C}$ at Selinus, whose results are presented here, was directly influenced (as well as limited) by the overall very poor state of preservation of the monument. The rare remains of white stuccoes on the capitals and columns of the northern peristasis (fig. 3-5), and the extant traces of polychromy (fig. 2, 4, 6) were micro-sampled by the technicians of the restoration firm L'ISOLA laboratori di restauro after an accurate autoptic study of the stratigraphy of such traces. Samples were then examined at the LAMA (Laboratorio di Analisi dei Materiali Antichi) of the University IUAV of Venice (Italy) in order to determine the nature of the constituent materials and the chronological sequence of the stratigraphic units of the coatings ${ }^{21}$. This allowed collecting information on the execution technique and reconstructing possible and coherent images of the temple over time.

All types of surviving mortars and stuccoes (original, and pertaining to ancient restorations), as well as of pigments, were sampled and examined in the laboratory with minero-petrographic and chemical methods that included the microscopic study under transmitted-reflected polarized light of thin and polished sections (OM, Leitz DM RXP), X-ray powder-diffraction (XRD, PANanalytical Empyrean operating with CuKa at $40 \mathrm{KV}, 20 \mathrm{~mA}$ ), scanning electron microscopy (SEM, Philips XL30) coupled with qualitative and quantitative chemical analyses by energy-dispersive spectrometry (EDS, EDAX Ametec operating at variable Kev) directly on samples and on their polished and thin cross-sections.

\section{Results and discussion}

The obtained results allow distinguishing and identifying the following stratigraphic sequence of the surface treatments on the columns and capitals (starting from their flattened stone):

SU 1. A yellowish lime mortar (in Italian called rinzaffo or rattoppo) containing abundant aggregate formed by local dune-river sand (fig. 2): this putty imitates the color of the Selinuntine biocalcarenite and was applied to fill the natural irregularities (small cavities/very large pores) that were quite frequent in the non-homogenous quarried stone.

SU 2. A thin red-ochre layer found in the grooves of the annuli of the capitals (fig. 3): it was brushed directly on the calcarenite below the white stucco since the red layer partially impregnated the stone substratum underneath (thin section in fig. 3), and should thus have been applied in a liquid suspension (probably with the addition of a medium such as animal glue).

SU 3. A rather thin and compact yellowish arriccio made of lime mixed with a small amount of dune or river sand (fig. 4). Its composition is similar to that of the rinzaffo though generally with a finer aggregate (polished cross-section in fig. 4). It was a preparatory layer, normally a few millimeters to about half a centimeter thick, originally probably present all over the columns and capitals and on all other surfaces, except for the annuli and all those minute details of which it would inevitably alter the morphology.

SU 4. A white stucco (intonaco) (fig. 4) composed of lime and of a small amount of aggregate formed by white limestone 
clasts (polished cross-section in fig. 4): it was applied fresco su fresco on top of the arriccio, that is, by wetting this layer with a cloth and/or brush while the layer was still drying (macrophotograph in fig. 4). Unfortunately no traces of polychromy was found over the original white intonaco.

SU 5. A subsequent white coating that looks like a sort of marmorino (fig. 5) made by mixing lime with a small amount of aggregate formed by ground calc-sinter (calcite di vena in Italian) ${ }^{22}$, finely crushed in a mortar to obtain an artificial aggregate that would reflect well the sunlight. Its presence is characterized by clasts showing the typical rhombohedral cleavage (photomicrographs of thin sections in fig. 5). These are clearly traces of later work of "modernization": this ground calc-sinter aggregate is in fact fully comparable with that found in intonacoes of temple $\mathbf{B}$, and thus it may be dated to the same Early Hellenistic period ${ }^{23}$.

SU 6. Traces of a blue layer on top of the marmorino (polished cross-section in fig. 6); it was found only on the renovation stucco (Early Hellenistic?). In the corresponding polished section, the finely ground Egyptian blue appears intimately mixed with lime, indicating a pittura alla calce (limewash) technique ${ }^{24}$. Some other traces of polychromy, namely of a yellow layer made of yellow ochre (fig. 6) were observed on top of a thin white stucco that covers the grooves of the annuli; the polished cross-section in fig. 6 shows areas impregnated by this ochre indicating the use of a sort of fresco technique (the yellow pigment was very likely applied distempered in water before the setting of the intonaco's lime).

Traces of a final maintenance limewash (intonachino-scialbatura) made of pure calcite, without aggregate, were observed on the white marmorino (SU 5) and no trace of polychromy has survived on the columns.

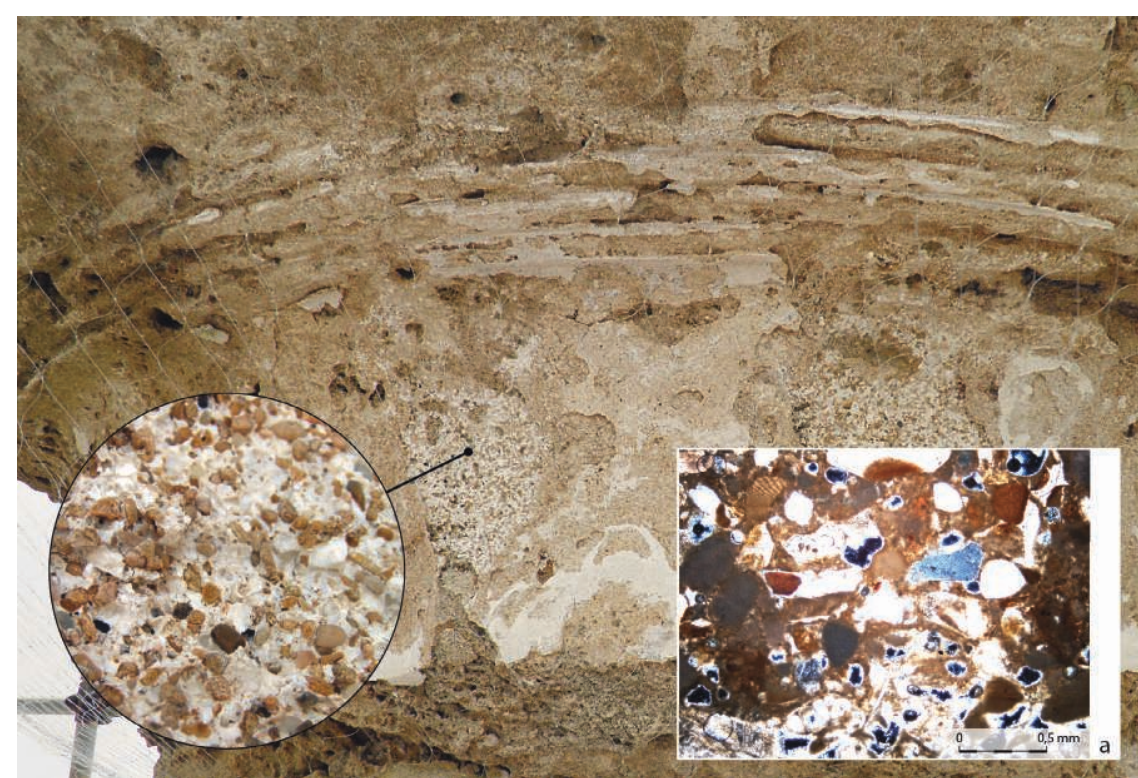

Fig. 2. Capital IX, a coarse lime mortar rinzaffo locally used to fill the natural irregularities of the non-homogeneous stone. a. Thin section of the yellowish lime mortar, showing the collophorm calcite with abundant dune-sand aggregate. $\mathrm{N}+$, long side $=2.35 \mathrm{~mm}$. Grafic elaboration: A. Tomaselli. (C) K. D'Ignoti/L. Lazzarini.

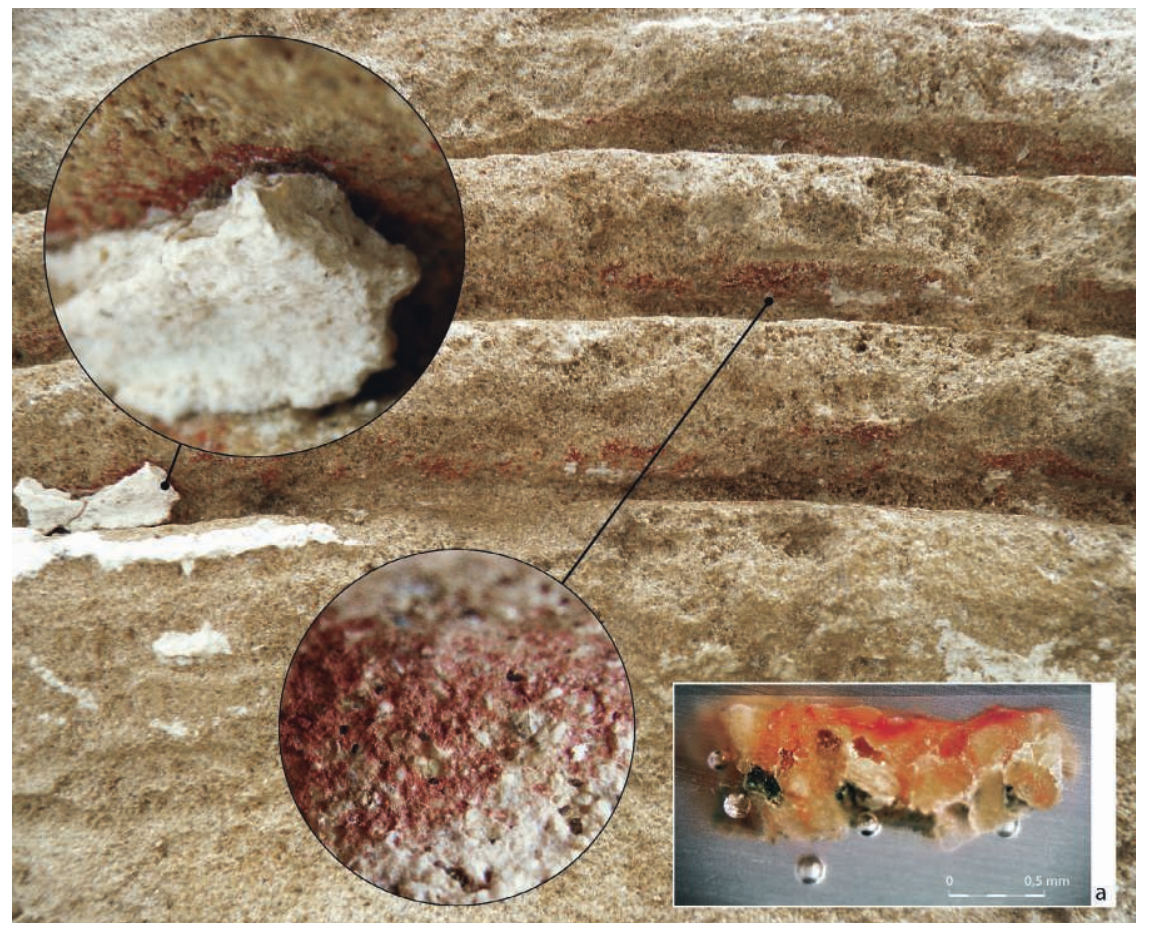

Fig. 3. Annuli of the capital VIII. Red paint brushed directly on the calcarenite, below the white stucco (SU 2). a. Polished cross-section showing the red layer partly impregnating the stone substratum. Reflected light, long side $=2.3 \mathrm{~mm}$. Grafic elaboration: A. Tomaselli. (C) K. D’Ignoti/L. Lazzarini.

\section{Conclusions}

The observations in situ and the results of the archaeometric studies allow us to conclude that the original white stucco (SU 4) was either laid directly over the yellow biocalcarenite used for building the temple, or over a yellowish preparatory layer (arriccio). In the annuli of the capitals, this stucco was applied above a thin layer of red ochre. It is most likely the very color described by the Duke of Serradifalco: "circostanza singolarissima, che il capitello di uno de' triglifi scorgesi pria 


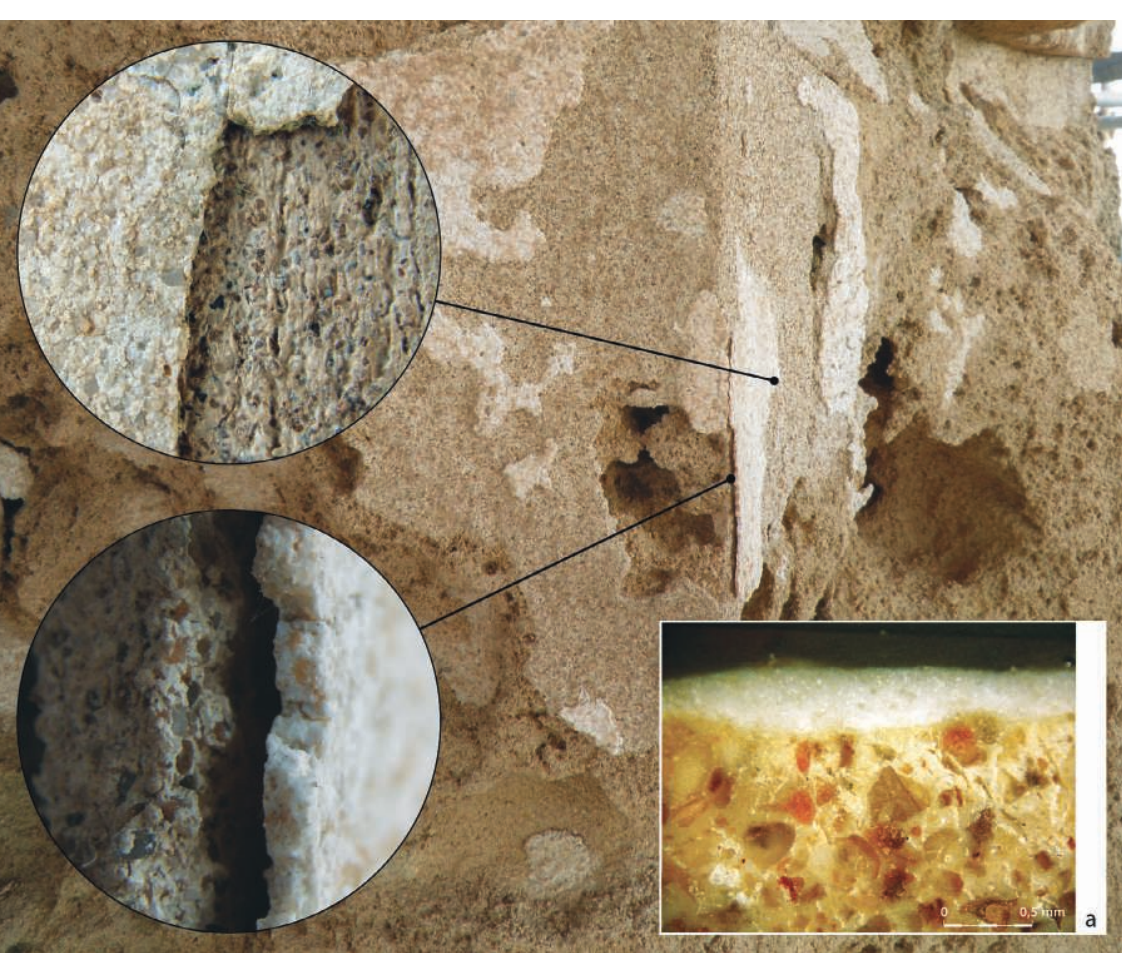

Fig. 4. Drum of column VIII with the original white intonaco (SU 4) applied on top of the arricio ( $\mathrm{SU} 3$ ). a. Polished cross-section (long side $=2.3 \mathrm{~mm}$ ) showing the stratigraphy with the intonaco, composed of lime and of a small amount of aggregate formed by small white limestone clasts, over a fragment of the yellow preparation (arriccio) made of lime mixed with a small amount of dune or river sand. Grafic elaboration: A. Tomaselli.

(c) K. D'Ignoti/L. Lazzarini.

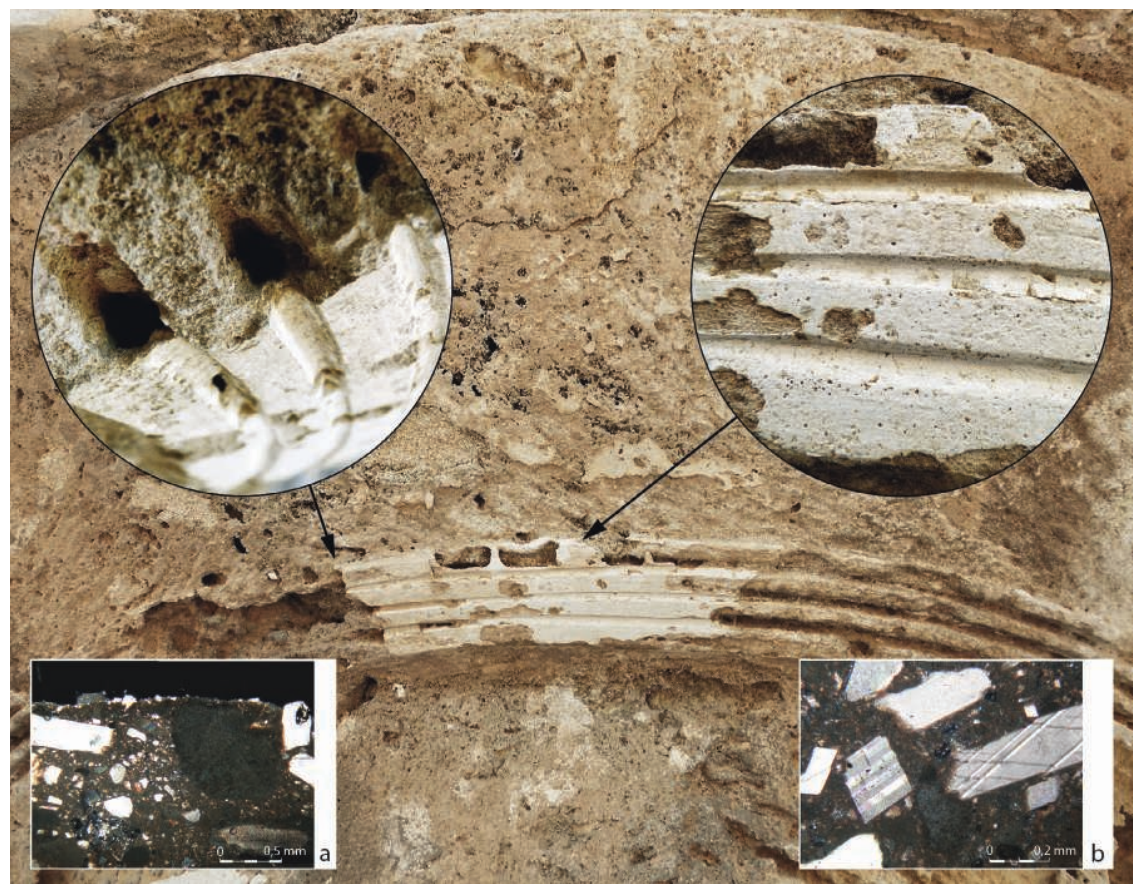

Fig. 5 a-b. Annuli of the capital XI: traces of later work of "modernization" with a white coat that looks like a sort of marmorino containing an aggregate formed by calc-sinter (SU 5). a. Photomicrograph of the thin section of the new intonaco, showing a calcinello (a lime inclusion) and an aggregate obtained by crushed calc-sinter. $\mathrm{N}+$, long side $=2.3 \mathrm{~mm}$.

b. Thin-section showing clasts with the typical rhombohedral cleavage of calc-sinter. N+, long side $=0.95 \mathrm{~mm}$. Grafic elaboration: A. Tomaselli. @ () K. D’Ignoti/L. Lazzarini. 


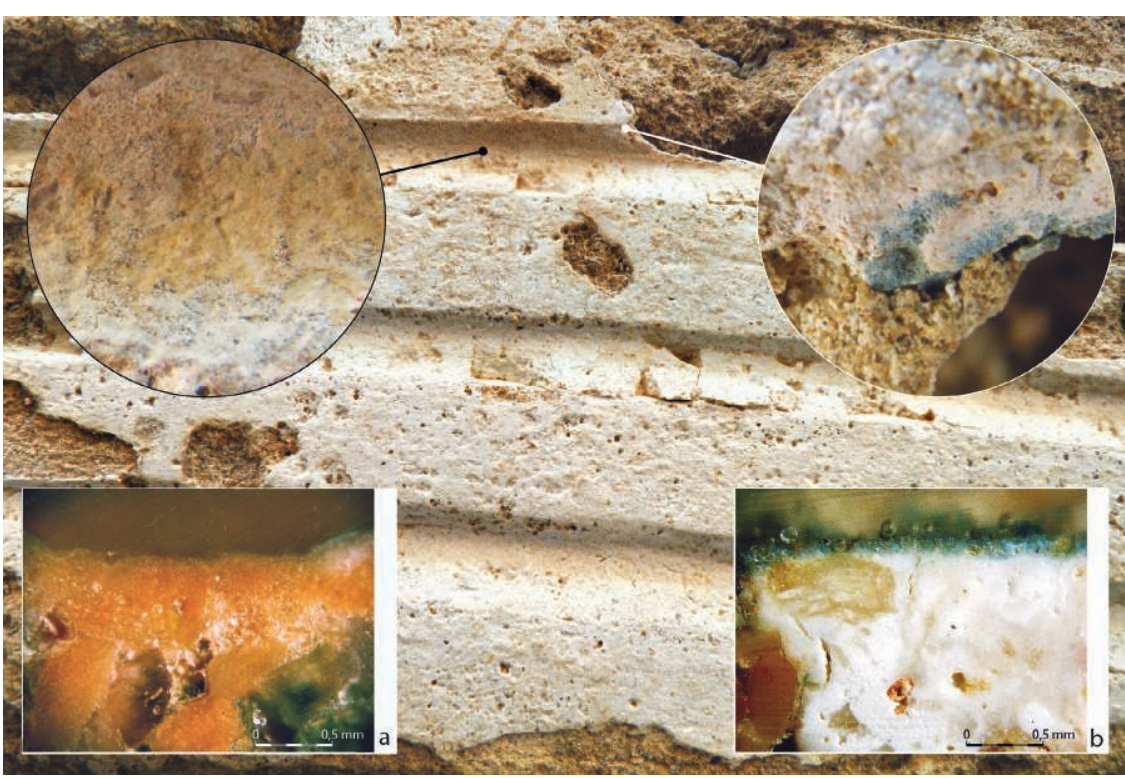

Fig. $6 a-b$. Annuli of the capital XI. Traces of a later work of "modernization" with a white coat that looks like a sort of marmorino as for fig. 5. a. Polished cross-section showing a yellow-ochre layer on a thin white intonaco. Reflected light, long side $=2.3 \mathrm{~mm}$. b. Polished cross-section showing a layer of Egyptian blue on top of the thick white intonaco. Reflected light, long side $=2.3 \mathrm{~mm}$. Grafic elaboration: A. Tomaselli. (C) K. D’Ignoti/L. Lazzarini.

di rosso sulla pietra dipinto, poscia intonacato di stucco, ed in fin ridipinto del colore medesimo ${ }^{25}$." It could have been the first and most ancient chromatic decoration of this and other Siceliot temples ${ }^{26}$. This hypothesis is supported by the observation of the frequent presence of extensive red areas on the entablature and altar elements from the Athena temple of Syracuse $^{27}$ (fig. 7), kept at the local Paolo Orsi Archeological Museum, and on the fragments of cornice from the archaic temple of Heracles in Agrigento (fig. 7), kept at the Antonino Salinas Museum in Palermo.

According to this hypothesis, proposed here for the first time, the capitals would thus have been characterized by the same chromatic finish as the famous metopes and conceived for the same context. On the other hand, Marconi does not hesitate to attribute the plan of the sculptures of the frieze of temple $\mathrm{C}$ to the $\operatorname{architect}^{28}$. The latter used methods of polychrome finishing similar to those preceding the "petrification phase" of which temple C is one of the first examples ${ }^{29}$. Clearly, this decorative technique could not imitate the marble temples, which even in the motherland are attested only in a later historical period. The use of polychrome clay tiles would also be replaced in Selinus by Parian marble tiles later on, for example in temple A.

However, neither of the two plasters identified by us (SU 4 and SU 5) contains any trace of "blanc de Sélinonte", a local white chalk or clay that would have been used, according to Jean Hulot and Gustave Fougères, "dans la composition des enduits $^{30 "}$. Thus the reconstruction that the two Frenchmen

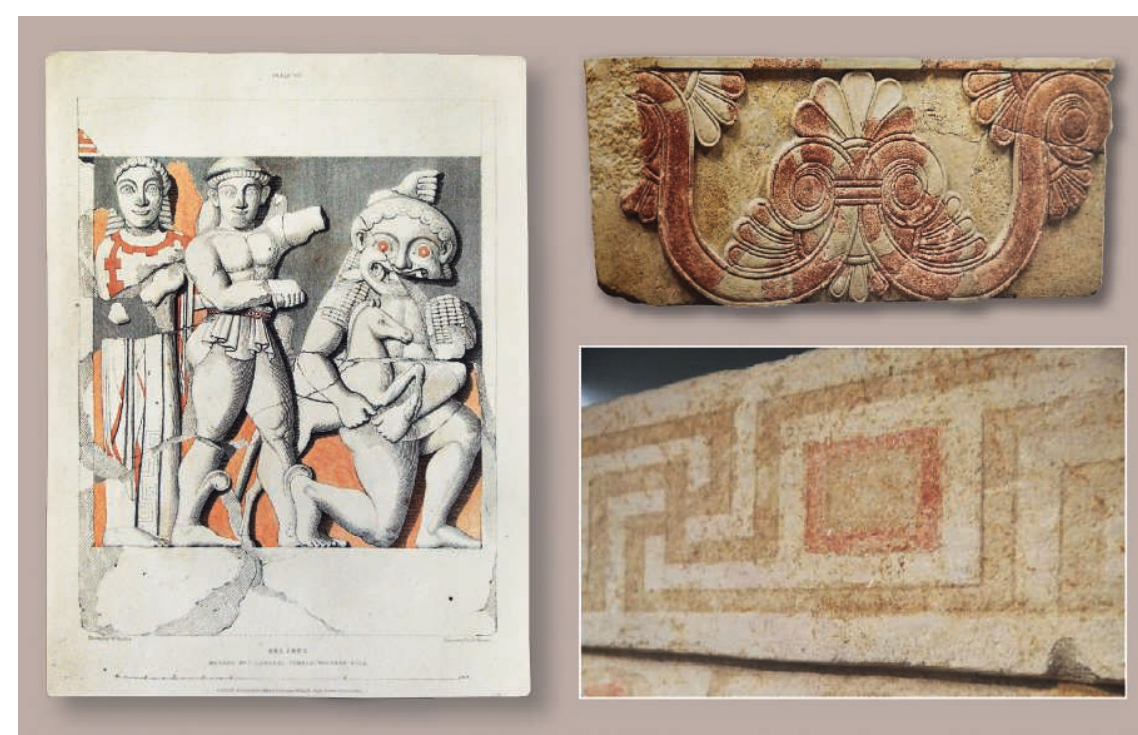

Fig. 7. The Harris and Angell's watercolour of the Gorgon metope (Angell, Evans, 1826) (left); the altar frieze of the Syracusan Athenaion (local calcarenite, inv. 34603, $226 \times 95 \times 36 \mathrm{~cm}$ ) in the P. Orsi Museum, Syracuse (upper right), and a fragment of the cornice of the Heracles' temple of Agrigento (local calcarenite, inv. 66268, $49 \times 19 \times 9 \mathrm{~cm}$ ) in the A. Salinas Museum, Palermo. (C) G. Alfano. 
would go on to make of the chromatic apparatus, according to which "la polychromie des parties hautes, corniches, cimaises, tuiles faîtières en terre cuite faisait un diadème chatoyant et pittoresque à la façade d'une blancheur marmoréenne", while "la couleur rouge était appliquée sur les parties ombrées pour les réchauffer ${ }^{31}$ ", can be considered reliable only if referred to the second phase (whether Late Archaic or Classical) when the surfaces were probably already eroded and may have required a new coating for protective purposes. The same can perhaps be said of the Early Hellenistic phase, when the shapes of the capitals were remodelled in stucco (SU 5), thus concealing the engravings of the annuli that were reshaped with a new profile $^{32}$. The metopes, however, were devoid of the white coating, preserving their archaic appearance, as Harris and Angell
The information gathered here, though insufficient largely due to the lack (or extremely poor state of conservation) of the original surfaces of temple $\mathrm{C}$, is however very useful to reconstruct the original aspect of one of the most important Archaic temples of the western Mediterranean Greek colonies.

\section{Acknowledgments}

The authors wish to warmly thank Caterina Greco, former director of the "Vincenzo Tusa" Archaeological Park of Selinunte for authorizing the sampling and encouraging our studies.

\section{Notes}

1. For the peculiar architecture of this temple and its Siceliot context, see Gullini, 1985. For the most recent bibliography on the same subject and on the restoration pespectives of the Selinuntine temples, see Mertens, 2016.

2. On these two brilliant British architects/travelers whose activity was compared to that of Lord Elgin, see Angell, Evans, 1826; Pisani, 1823 (ristampa, 1998); Marconi, 2008.

3 . For the re-constructions of temples at Selinus, see Tusa, 2016 2016.

4. A detailed description in Genovese,

5. Though not fully satisfactory, the restoration performed by Valenti resisted well to the powerful Belice Valley earthquake in 1968.

6. Bennardo, Mannuccia, 2016, and bibliography therein.

7. For a minero-petrographic and physical characterization of the biocalcarenite, see Lazzarini, 2016.

8. Angell, Evans, 1826, p. 35.

9. This is confirmed by various sources, including Charles Robert Cockerell who, in referring to the Olympeion of Akragas, noted: "The whole of this sculpture and the architecture was coloured with a thin coat of hard plaster presenting a surface like the finest marble", Cockerell, 1830, p. 5.

10. Politi, 1826, p. 16, wrote "tutto era impelliciato di calce, leggermente colorata a varie tinte" ("everything was coated with lime, slightly coloured in various shades").

11. Some porosity measurements by mercury intrusion on the biocalcarenite of
Selinunte gave an open porosity of about $28 \%$ (Lazzarini, 2016, p. 150). On the need for a stucco, see also Lazzarini, 2009, p. 138. 12. The Duke of Serradifalco believed that the stucco could have been applied to "preservare dalle ingiurie dell'aria, delle piogge e degli anni i loro tempî (...) onde gli artisti della Grecia si valsero di questo modo di conservazione..." ("to preserve their temples from the ravages of the air, rain and years (...) so the artists of Greece adopted this method of conservation..."): Lo Faso Pietrasanta di Serradifalco, 1834, vol. II, p. 26.

13. On the use of colour in ancient architecture and sculpture in the 19th century, see Hittorff, 1851; Wünsche, 2004; Marconi, 2008.

14. Hittorff, 1851, p. 595-596 ("He insists on the important and cogent observation that regardless of the beautiful appearance of the uniform surface of the stuccoes, instead of the unpleasant sight of a porous material, this applied layer essentially preserves the stones; and exalts with no less genuineness how much the smoothness given to the hardest marbles and granites, as well as the layer of cauterized wax, the kav̄si $\zeta$ coating which covered these fine materials, contributed to their beautiful preservation and durability").

15. Marconi, 2008, p. 79 ("has been raging for years in French academia, ultimately spreading to other European countries").

16. Lazzarini, 2009, Lazzarini, Marconi, 2016.

17. For architecture, see Campisi, 1987.

18. See for example the relevant contributions in the catalogue of the important exhibition "I colori del Bianco" held at the Musei Vaticani, and the references reported therein.

19. Lazzarini, 2009.

20. Lazzarini, Marconi, 2016, p. 193

21. According to a procedure that follows the archaeological method of reconstructing stratigraphic units, even far away from each other. This method, established by Harris, is based on the presence of the same characteristics shared by these units: an explanation and comment on this method can be found in Arce $e t$ al., 1996.

22. This calc-sinter was obtained by grinding calcite alabasters/speleothems (such as stalactites) that are common in the caves-quarries of the Menfi area, a few kilometers away from Selinunte.

23. Lazzarini, Marconi, 2016, p. 196.

24. Also identified in the blue areas of the Selinuntine Temple B, Lazzarini, Marconi, 2016, p. 195.

25. Lo Faso Pietrasanta di Serradifalco, 1834 , p. 29 ("a very unique circumstance that the capital of one of the triglyphs features red paint on the painted stone, then plastered with stucco, and finally painted again with the same colour").

26. Another possibility is that it may have been connected to the incision of the annuli as a check of their depth and precision, or a "check layer" pertaining to a manufacturing phase (control of the surface-flattening of the stone).

27. "Tutta l'opera di rilievo è poi ravvivata da una forte colorazione a guazzo di un rosso sanguigno, che malgrado i 24 secoli trascorsi, in gran parte sotterra, mirabilmente resiste e si conserva (...). ̀̀ 
una decorazione semplice, austera e quanto mai vigorosa, di vivace effetto decorativo, anche per l'impiego del colore rosso-fuoco" ("All the reliefs are then enlivened by an intense blood-red gouache colouring, which, in spite of the 24 centuries that have passed, most of which underground, admirably resists and is preserved (...). It is a simple, austere and very vigorous decoration, with a lively decorative effect, thanks also to the use of the fire-red colour"). Orsi, 1918, p. 693-695.

28. Marconi, 2006, p. 622.

29. "The great revolution that Greek architecture, understood in the broadest geographical sense, experienced in the course of the seventh and first half of the sixth centuries, consisted (...) in the introduction and progressive spread of the use of stone throughout the edifice, to the point of making it the raw material which, from now on, would characterize all the manifestations of Greek architecture almost as a distinctive mark" (Gullini, 1994).

This "petrification process" was reflected in the mother country, but it featured many original Sikeliot characteristics and the Temple $\mathrm{C}$ is a key link in its evolution with the transition from monolithic columns to those made of drums that took place for the first time during its long construction. The present study offers an interpretation of the evolution of the coloured coating, starting from the traces unexpectedly found and from the reflections made during the course of this long effort.

30. Hulot, Fougères, 1910, p. 30 ("in the composition of the plasters"). There is no certainty whether "craie de Sélinonte" ("earth/clay of Selinus"), as called by the two Frenchmen, was actually invented in Selinus. Moreover, this type of "earth" was very likely a marly limestone that could not be used as a plaster, but rather as a pigment (in fact, this is the case mentioned by Selim Augusti in his book on the colours of Pompeii, Augusti, 1967). In addition, no deposits of white clay have been found to date in Selinunte and the surrounding area. Strabo and Pliny mention a river called Selinus in various places of the ancient world: in Achaea, in Ilia, and also near the city of Ciliea as well as in Ephesus, where there was also a lake with the same name into which the river Caystrus flowed. Therefore, the statement made by Hulot and Fougères is not, in our opinion, reliable.

31. Hulot, Fougères, 1910, p. 226-227 ("the polychromy of the upper parts, cornices, friezes, and terracotta ridge tiles constituted an iridescent and picturesque diadem on the facade of a marmoreal whiteness", while "the red colour was applied on the shaded parts to warm them"). An anastatic edition of this work was recently published by the Centro Regionale per l'Inventario, la Catalogazione e la Documentazione of the Sicily Region.

32. Robert Johann Koldewey and Otto Puchstein reported the "modernization" of the profiles of the annuli: "Aus derselben Zeit dieser Modernisierung stammen: die schuppenförmige Veränderung der ursprünglich gleichschenkligen Kerben am Ringband, (...) Der Stuck der Säulen kennzeichnet sich somit als bedeutend späterer Zeit angehörig" ("Of the same period of this 'modernization' comes the deterioration of the incisions in the band of anuli originally of an isosceles shape (...) the stucco of the columns is thus marking itself to pertain to a much later period"). Koldewey, Puchstein, 1899, p. 99.

\section{Bibliography}

Angell S., Evans T., 1826, Sculpted metopes discovered amongst the ruins of the temples of the ancient city of Selinus in Sicily by William Harris and Samuel Angell, in the year 1822, Priestley and Weale, London.

Arce I., Doglioni F., Parenti R., 1996, "Gli strati di rivestimento: strategie e tecniche di indagine tra conoscenza dello spessore storico e finalità di conservazione/restauro", in Dal sito archeologico all'archeologia del costruito, Atti del Convegno di Studi Bressanone, Padova, 3-6 luglio 1996, Arcadia Ricerche, Padova, p. 39-48.

Augusti S., 1967, I colori pompeiani, De Luca Editori d'Arte, Roma.

Bennardo C., Mannuccia F., 2016, "Restauri in corso al tempio C di Selinunte. Una chiave di accesso alla conoscenza dei capitelli arcaici", in SELINUNTE, Restauri dell'Antico, Atti del Convegno, Selinunte, 20-23 ottobre 2011, De Luca Editori d'Arte, Roma, p. 153-176.

Campisi M., 1987, "L'evidenza archeologica: l'architettura", in A. Melucco Vaccaro (ed.), I colori perduti, la policromia nell'architettura e nella scultura classica, Dossier di Archeo, 29, p. 24-43.

Cockerell Ch. R., 1830, The Temple of Jupiter Olympius at Agrigentum, commonly called the Temple of the Giants, Priestley and Weale, London.

Genovese C., 2006, Francesco Valenti e la cultura del restauro dei monumenti nella Sicilia del primo Novecento, Ph. D., Università degli Studi di Napoli Federico II, Napoli.

Genovese C., 2016, "Restauri archeologici nel primo Novecento. Le anastilosi del tempio $\mathrm{C}$ a Selinunte e del Tempio di Eracle ad Agrigento", in SELINUNTE, Restauri dell'Antico, Atti del Convegno, Selinunte, 20-23 ottobre 2011, De Luca Editori d'Arte, Roma, p. 79-90.

Gullini G., 1985, "L'architettura", in G. Pugliese Caratelli (ed.), Sikanie. Storia e civiltà della Sicilia greca, Istituto Veneto di Arti Grafiche, Milano, p. 415-491.

Gullini G., 1994, sub voce "Arte Greca Architettura", Enciclopedia dell'Arte Antica, vol. III, Roma, p. 1005.

Hittorff J. I., 1851, Restitution du temple d'Empédocle à Sélinonte, ou l'architecture polychrôme chez les Grecs, 2 vol., Firmin Didot Frères, Paris.

Hulot J., Fougères G., 1910, Sélinonte, ville dorienne de Sicile. La ville, l'acropole et les temples, Ch. Massin Éditeur, Paris.

Jockey P., 2013, Le mythe de la Grèce blanche.
Histoire d'un rêve occidental, Éditions Belin, Paris.

Koldewey R., Puchstein O., 1899, Die griechishen Tempel in Unteritalien und Sicilien, Asher Verlag, Berlin.

Lazzarini L., 2009, "Indagini archeometriche sugli intonaci dei templi di Selinunte", in C. Antonetti, S. De Vido (eds.), Temi selinuntini, Edizioni ETS, Pisa, p. 138-158.

Lazzarini L., 2016, "La calcarenite gialla dei templi di Selinunte: cave, caratterizzazione, problemi di conservazione", in SELINUNTE Restauri dell'Antico, Atti del Convegno, Selinunte, 20-23 ottobre 2011, De Luca Editori d'Arte, Roma, p. 145-152.

Lazzarini L., Marconi C., 2016, "A scientific analysis of the polychromy of temple B at Selinunte", in M. Kiene, L. Lazzarini, C. Marconi (eds.), Sicile Ancienne. Hittorff and the architecture of Classical Sicily, Schriften 23, Universität und Stadtbibliothek Köln, Cologne, p. 193198.

Lo Faso Pietrasanta Di Serradifalco D., 1834, Le antichità della Sicilia esposte ed illustrate, A. Altieri, Palermo, vol. II.

Marconi C., 1995, "Due studi sulle metope figurate dei templi 'C' e 'F' di Selinunte", Rivista dell'Istituto Nazionale di Archeologia e Storia dell'Arte, 18, p. 5-67.

Marconi C., 2006, "Le metope arcaiche di Selinunte. Un riesame", in Guerra e pace in Sicilia e nel Mediterraneo antico (VIII-III sec. A.C.), Arte, prassi e teoria della pace e della guerra, vol. II, Atti delle quinte giornate internazionali di studi sull'area elima e la Sicilia occidentale nel contesto mediterraneo, Erice, 2003, Edizioni della Normale, Pisa, p. 621-630.

Marconi C., 2008, "Il tempio B di Selinunte: Hittorff, Serradifalco e la disputa sulla policromia dell'architettura greca nell'Ottocento", Sicilia Antiqua, IV, p. 59-91.

Mertens D., 2016, "I templi e la città. Problemi e prospettive del restauro architettonico a Selinunte", in SELINUNTE, Restauri dell'Antico, Atti del Convegno, Selinunte, 20-23 ottobre 2011, De Luca Editori d'Arte, Roma, p. 13-58.

Orsi P., 1918, "Gli scavi intorno all'Athenaion di Siracusa negli anni 1912-1917”, Monumenti Antichi, vol. XXV, Hoepli, Milano.

Pisani P., 1998, Memoria sulle opere di scultura in Selinunte ultimamente scoperte (Palermo, 1823), ristampa, Maimone, Catania.

Politi R., 1826, Il viaggiatore in Girgenti o il cicerone di piazza, ovvero guida agli avanzi di Agrigento, Lipomi, Girgenti.

Tusa V., 2016, "Luci ed ombre delle ricostruzioni selinuntine", in SELINUNTE, Restauri dell'Antico, Atti del Convegno, Selinunte, 20-23 ottobre 2011, De Luca Editori d'Arte, Roma, p. 91-98.

Wünsche R., 2004, "Il colore ritorna", in P. Liverani (ed.), I colori del bianco: Policromia nella scultura antica, De Luca Editori d'Arte, Roma, p. 13-27. 